\title{
Teaching Material Development of Islamic Education in Multicultural Perspective at Smk Negeri 4 Manado
}

\author{
Mastang Ambo Baba ${ }^{1}$, Arismunandar ${ }^{2}$, Baso Jabu ${ }^{3}$ \\ ${ }^{1}$ Department of Educational Science,Universitas Negeri Makassar \\ Jln. Bonto Langkasa Kampus Gunung Sari Baru, Makassar, South Sulawesi, Indonesia \\ IAIN Manado \\ Jl. Manguni Raya, Manado, North Sulawesi, Indonesia \\ Email: mastangambobabal [AT] gmail.com \\ ${ }^{2}$ Department of Educational Science, Universitas Negeri Makassar \\ Jln. Tamalate 1, Makassar, South Sulawesi, Indonesia \\ Email: arismunandar [AT] unm.ac.id \\ ${ }^{3}$ Department of Language and Literature, Universitas Negeri Makassar \\ Jln. Malengkeri 1, Makassar, South Sulawesi, Indonesia \\ Email:basojabu [AT] unm.ac.id
}

\begin{abstract}
This study aims to describe the level of validity, practicality and effectiveness of Islamic Education teaching materials in a multicultural perspective. The procedure for developing teaching materials is conducted by adapting Research and Development (R\&D) using the Four-D model. The research subjects were Islamic education teachers and 30 students of class XI. Data collection was conducted using interview techniques, questionnaires, and the feasibility assessment sheet, practicality, and effectiveness of the product. The results showed that the teaching material products in the form of books for students as companion books on Islamic Education subjects were in the very valid category. The results of expert tests on Islamic Education teaching material products showed very valid criteria assessment. While the learning tools which include: learning implementation plans, teacher and student observation sheets and learning outcome assessment instruments are in the very valid category. The teaching material products developed meet practical criteria based on the target user test, namely educators on the ability of educators to manage the learning process with a fully implemented category as well as educators' responses to teaching material products are very positive. Teaching material products are effective because of a positive response from students and an increase in learning outcomes after using these teaching material products.
\end{abstract}

Keywords---- Development, Teaching Materials, Islamic Education, Multicultural

\section{INTRODUCTION}

Islamic Education as one of the subjects that must be taught at all levels of education. Islamic Education learning in SMA / SMK is intended to increase spiritual potential and shape students to become human beings who believe and have devotion to God Almighty and have noble character. Noble morals include ethics, manners, and morals as the manifestation of religious education. Increasing spiritual potential includes the practice, understanding and cultivation of religious values, as well as the practice of these values in individual or collective social life. The increase in spiritual potential is ultimately aimed at optimizing the various potentials possessed by humans whose actualization reflects their dignity as God's creatures. Islamic Education in schools can be understood as an educational program that instills Islamic values through the learning process, both in class and outside the classroom which is packaged in the form of subjects and is named Islamic Education which is abbreviated as Islamic Education (Syahidin, 2009: 1) [1]. 
Several criticisms have been leveled against Islamic Education in schools, that it is precisely through these lessons that excessive fanaticism often develops, thus burying efforts of tolerance. This criticism is undeniable because in religious education, especially Islamic Education, so far it is more concerned with the cognitive realm, which is limited to memorizing texts without any meaning to reality, as if ignoring the affective aspects that require deep reflection and appreciation. Islamic Education should not be limited to the transfer of knowledge, but to the depth of the transfer of value.

The discourse of multiculturalism in the context of education in the current reformation era has become an important issue in efforts to build society in Indonesia. Indonesia is a diverse nation in terms of culture, ethnicity, language and religion. On the one hand, religious plurality is a capital for cultural wealth and provides benefits for the Indonesian nation because it can be used as a very rich source of inspiration for the process of consolidating democracy in Indonesia. But on the other hand, plurality can also have the potential to create social conflicts between religious communities that can threaten the integrity Republic of Indonesia, especially if such diversity is not addressed and managed properly. Tilaar (2002: 37) [2] states that the occurrence of conflict in a pluralistic or multicultural country is undeniable, because in a country where a multicultural society on the one hand holds a lot of strength from each group, on the other hand it saves the seeds of division if not. well managed and rational.

Because the socio-cultural conditions of the nation and state of Indonesia are very diverse, multicultural learning is a must. Multicultural learning according to Banks (2010: 28) [3] is a concept or idea as a set of beliefs and explanations that recognize and assess the importance of cultural and ethnic diversity in shaping lifestyles, social experiences, personal identities and opportunities from educational background of individuals, groups and countries.

Multicultural learning is also explained by Dantes (2015: 2-3) [4] as an understanding, appreciation, and assessment of one's culture, a respect and curiosity about other ethnic cultures, not in the sense of agreeing to all aspects of these cultures, but trying to see how culture is can express value for its members.

According to Nieto (2002: 29) [5] this multicultural education must be embedded in the curriculum and teaching strategies, including in every interaction between educators, students, families, and the overall learning atmosphere. This type of education is a critical pedagogy, reflection and the basis for change action in society. Consequently, it is assumed that multicultural education is capable of developing democratic principles in social justice.

Radicalism, intolerance and terrorism are stages that need to be immediately anticipated. Radical thinking that has emerged recently as a form of error in interpreting religious teachings and belief systems of religious adherents has become the forerunner to the birth of intolerance that will even lead to acts of violence and murder in the form of terror in the community. In Indonesia itself, acts of terror were not driven by uneducated people, but instead, radicalism was born from educated circles.

Schools play an important role in instilling multicultural values in students from an early age. If from the beginning they have had the values of togetherness, tolerance, peace-loving, and respect for differences, then these values will be reflected in their daily behavior because they are formed in their personality. If this is successfully owned by the younger generation, then life in the future can be predicted that a relatively peaceful and full of respect between each other can be realized.

The use of Islamic Education teaching materials in a multicultural perspective is expected to increase students understanding of the perspective, how to behave and act well. Multiculturalism in Islamic Education at the secondary school level can be done by providing in-depth and holistic material about Islamic teachings so that students will be open and tolerant to accept all kinds of diversity within the scope of Islamic teachings. Trying to provide an understanding of the process of creating an Islamic product, thus students have a philosophical understanding of a legal provision in an Islamic teaching.

Based on the background of the formulation of multicultural education above, it is clear that multicultural integration in subjects is one of the dimensions that must be carried out. In this context, no less important is how to integrate Islamic Education subjects in developing multicultural perspective among students in formal educational institutions by utilizing the teaching materials in a multicultural perspective.

\section{LITERATURE REVIEW}

Teaching materials are one of the important factors beside the factors of educators, students, facilities and infrastructure and other components. The interaction between these components is very important in achieving the learning goals that have been designed by educators. Good teaching materials will be able to motivate students to study harder and be able to develop the potential of students.

Teaching material is basically a tool in the form of learning content that is used by educators to further direct learning so that learning objectives can be achieved. These teaching materials become a guide for educators and students to achieve learning indicators that have been set in the curriculum. Interesting and innovative teaching materials are very important 
and are a guide for educators. This is in accordance with the opinion of Daryanto and Dwicahyono (2014: 171) [6], that teaching materials have the aim of making it easier for educators to carry out learning and are useful in building effective learning communication between educators and students, because students will feel more trust in their educators.

Teaching materials are all forms of materials used to assist educators in carrying out learning activities in class. According to Mudlofir (2011: 128)[7], teaching materials can be written or unwritten materials. Teaching materials can also be interpreted as information, tools or text that are needed or used by educators to plan and examine the implementation of learning.

In addition, Sadjati in Setiawan (2012: 6) [8] states that: "Teaching materials are very unique and specific. Unique means that the teaching material can only be used for certain audiences in a certain learning process. Specific means that the content of the teaching material is designed in such a way as to only achieve certain goals from a certain audience. The way to deliver is also adjusted to the characteristics of the subjects and the characteristics of the students who use them.

According to Marno (2011: 7) in Jufni (2015: 67) [9], teaching materials are materials or learning materials that are systematically arranged that are used by educators and students in the learning process. Then according to Mudlofir (2011: 127) in Jufni (2015: 67) [9] explains that teaching materials are all forms of material used to help educators / instructors in carrying out learning activities.

Teaching materials in the technical guidelines of the Directorate of Senior High School Development (2008: 6) [10] limit teaching materials as any form of material used to assist educators in carrying out learning activities. The material in question can be in the form of written material or unwritten material that can be used by students in developing their perspectives, knowledge and skills related to the subject matter being studied. This is intended so that students are not only fixated on the subject matter contained in the textbooks.

The use of this teaching material is expected to increase students' understanding of how to view, behave and act properly. Islamic Education in schools can be understood as an educational program that instills Islamic values through the learning process, both in class and outside the classroom which is packaged in the form of subjects and is named Islamic Education which is abbreviated as Islamic Education (Syahidin, 2009:1) [1]. Islamic Education is given by following the guidance that religion is taught to humans with a vision to create devout people to Allah SWT. and have a noble character, and aims to produce human beings who are honest, just, ethical, ethical, respectful, disciplined, harmonious and productive, both personal and social.

Multiculturalism in Islamic Education at the secondary school level can be done by providing in-depth and holistic material about Islamic teachings so that students will be open and tolerant to accept all kinds of diversity within the scope of Islamic teachings. Trying to provide an understanding of the process of creating an Islamic product, thus students have a philosophical understanding of a legal provision in an Islamic teaching.

Multicultural values that can be developed in Islamic Education teaching materials that are considered as essential to be developed include: 1) Love for peace as stated in the Qur'an, Q.S. al-Anfal (8); 61, 2) Love wisdom, 3) Q.S. Yunus / 10: 99, and 4) Respect plurality.

It is important to offer multicultural based Islamic Education (Harto, 2014: 25) [11] that because there is a tendency for religious followers to be intolerant of followers of other religions, exclusive, selfish, close-minded, and oriented to individual piety. Facing a multicultural community life needs to start from a change in the educational paradigm in Islamic Education. Islamic Education does not only use the learning to think, to do and to be paradigm, but also to live together.

If it is associated with Islamic Education as a field of study, according to Baidhawy in Harto (2014) [11] there are seven paradigmatic assumptions of multicultural based Islamic Education, namely: educating students to: 1) Learn to live in differences, 2) Build mutual trust, 3 ) Maintaining mutual understanding, 4) Upholding mutual respect, 5) Open minded, 6) Appreciation and interdependence, and 7) Nonviolent conflict resolution and reconciliation.

Multicultural learning can be used, at both descriptive and normative levels, to describe educational issues and problems related to multicultural societies. Furthermore, it also includes an understanding of the consideration of educational policies and strategies in a multicultural society. In a descriptive context, multicultural learning should contain themes regarding tolerance, ethno-cultural and religious differences, the dangers of discrimination, conflict resolution and mediation, human rights, democratization, plurality, universal humanity, and other relevant subjects. (Tilaar 2002: 15) [2].

James A. Banks formulates that multicultural learning is a concept, idea or philosophy as a set of beliefs and explanations that acknowledge and assess the importance of cultural and ethnic diversity in shaping lifestyle, social experiences, personal identity, learning opportunities. from individuals, groups and countries (Tilaar, 2002: 181) [2]. Furthermore, Dawam in Naim and Sauqi (2008: 50) [12] explained that multicultural learning is a process of developing all human potential that respects plurality and heterogeneity as a consequence of cultural, ethnic, ethnic, and religious diversity. Thus, multicultural learning requires the highest respect and respect for human dignity from wherever he comes from and whatever culture he is. 
The existence of multicultural learning in society cannot be separated from the function it carries. The Nation Council for Social Studies (Hanum, 2011: 101) [13] suggests a number of important functions of multicultural learning, namely: a) Providing a clear self-concept, b) Helping to understand ethnic and cultural experiences in terms of history, c) Helping to understand the conflict between the ideal and reality do exist in every community, d) Help develop decision making, social participation and citizenship skills, e) Recognize the diversity in language use.

Furthermore, (Zubaedi, 2005: 71) [14] argues that multicultural learning has at least 5 (five) goals, namely: a) Improve self-understanding and self-concept well, b) Increase sensitivity in understanding other people, including various cultural groups in his own country and other countries, c) Increase the ability to feel and understand diversity, interpretations of nationality and culture that sometimes conflict with respect to an event, values, and behavior, d) Open the mind when responding to issues, e) Understand the background of the emergence of views cliché or old fashioned, away from stereotypes and want to respect everyone.

The multicultural learning paradigm is expected to erase stereotypes, egotistical, individualistic and exclusive attitudes and views among students. On the other hand, it is always conditioned for the growth of a comprehensive view of others, namely a view that recognizes that one's existence cannot be separated or integrated with the surrounding environment whose reality is filled with a plurality of ethnicities, races, religions, cultures and needs. Multicultural learning reflects a balance between understanding cultural similarities and differences and encourages individuals to maintain and broaden their own cultural and cultural horizons.

From this it can be underlined that the basic value in multicultural learning is tolerance. This tolerant attitude will not be self-ingrained, but there must be a conscious effort to internalize it. Moreover, if the target is children, tolerance and multicultural learning must be instilled early on through various media and institutions, not necessarily fixed on formal institutions and government.

\section{RESEARCH METHODS}

This research is a research and development which refers to the 4-D development model (Thiagarajan et al, 1974), [15] namely Define, Design, Develop, and Deployment ( Disseminate). This research was conducted at the State Vocational High School (SMK) 4 Manado City in the odd semester 2019-2020. As the subject of the study were students in class XI in SMK 4 Kota Manado, totaling 30 people.

The product produced from this research and development is in the form of Islamic education teaching materials with a multicultural perspective in the form of books for participants as supplement books or companion books from Islamic Education textbooks used in schools. To produce good teaching materials, it is necessary to go through the stages of expert validation and revise them based on the results of field trials (Nieveen, 2010) [16].

The instrument used to assess the validity of teaching material products is the validation sheet of teaching materials that has been validated by 2 (two) experts (media experts and material experts). The criteria used to state that teaching material products have an adequate degree of validity refers to the results of the adaptation of Arsyad (2007: 159) [17] validity criteria. i.e. if the average value of validity for all aspects of the minimum is in the valid category $(2.5 \leq \mathrm{M}<3.5$ is the average value of validity of all aspects assessed) and the validity for each aspect is also in the valid category $(2.5 \leq \mathrm{M}$ $<3.5$ is the average value of the validity of each aspect assessed).

The instrument used to assess the practicality of teaching material products is the questionnaire responses of educators (users) and observation sheets of the ability of educators to manage learning by using teaching materials products with multicultural perspectives. The criteria established to state that educators have a positive response to teaching material products if the percentage of achievement of the minimum response agrees at least in the range of $51 \%-75 \%$ or in the good category (Hobri, 2010) [18]. Furthermore, the ability of educators in managing learning is adequate.

The learning implementation (KP) is in the minimum category "partially implemented" $(0.5 \leq \mathrm{KP}<1.5)$; based on the adaptation of the learning implementation category by Arsyad (2007) [17]. So, the product of teaching materials is said to be practical if the response of educators to the use of Islamic Education teaching material products with a multicultural perspective is positive and the level of educators' ability to manage learning is at least partially implemented.

The instruments used to assess the effectiveness of teaching material products were student response questionnaires, student activity observation sheets and test learning outcomes. The teaching material products developed are said to be effective if they meet the following requirements: (1) Positive student responses to the use of Islamic Education teaching material products with multicultural perspective during the learning process, (2) the involvement of students in the learning process is in the high category, (3) Results Student learning is shown based on the results of the pre test and post test of the objective test and performance test given using the t test.

Analysis of student response data was obtained from student response questionnaires to the use of Islamic Education teaching material products with a multicultural perspective in the learning process. The technique of analyzing student response data to teaching material products can be done by using a percentage, the percentage of observations about the 
student's response, namely the frequency of each aspect of the observation divided by the number of frequencies of all aspects of the observation multiplied by $100 \%$. The student response criteria (RPD) to Islamic Education teaching material products meet the positive response category if the students' responses are in the range of $61 \% \leq \mathrm{RPD}<80 \%$ in the interesting category or in the range of $81 \% \leq \mathrm{RPD} \leq 100 \%$ very attractive (Arsyad, 2007)[17].

The analysis of the observations of students' involvement in the learning process was carried out by calculating the percentage of the results of each observation of all student activities divided by the ideal answer score for all aspects of the observation multiplied by $100 \%$.

Furthermore, to determine the effectiveness of Islamic Education teaching material products with a multicultural perspective, an analysis of the pre test, post test and test was carried out. Student learning outcomes are declared to meet the effectiveness requirements if the pre-test and post-test results show that there is an average difference between the pretest and post-test results. Furthermore, to determine the degree of difference in the average before and after the use of Islamic Education teaching materials with multicultural perspective, Islamic Education red sample test or t-test analysis was carried out.

\section{RESULTS AND DISCUSSION}

Activities at the define stage produce information about: the perceptions of educators and students regarding the nature of the teaching materials they are currently using at SMK Negeri 4 Manado. The perception of educators that the Islamic Education teaching materials used are now more than 2 years old, the teaching materials are a means to develop religious competence in general, the available teaching materials are not sufficient to meet needs because they still need to add updated religious perspectives, The use of teaching materials is based on the initiative itself so it is necessary to add materials to strengthen the teaching materials used by involving related educators. While students' perceptions of the nature of teaching materials, in general, students want to use Islamic Education teaching materials to gain religious competence, especially those related to tolerance and mutual respect. Educators and students perceive constraints in the use of teaching materials related to

Activities at the design stage produce prototypes of teaching materials which include: student books, student activity sheets, and learning outcome assessment instruments. The results of the initial design of the teaching material product are first consulted with the promoter and co-promoter before validation by experts at the develop stage.

The develop stage is the validation and revision stage, namely the stage of developing Islamic Education materials / textbooks which consists of 2 (two) main activities, namely expert development (expert testing) and praxis development (testing the target users of Islamic Education textbooks / developed materials). The first activity carried out was an expert test of the teaching materials developed to determine the validity of the product by involving 2 (two) experts to be asked for their comments, suggestions, and criticisms of the initial prototype of the developed Islamic Education textbook / material. Activities at the develop stage produce teaching material products that have been revised based on expert input so that they are feasible to be tested. The two validators concluded that the product of Islamic Education teaching materials with a multicultural perspective that was developed could be used with a few revisions.

Expert response / input is used as the basis for determining the validity of the developed multicultural perspective Islamic Education material / textbooks. The results of the expert validity test that are deemed not meeting the requirements / eligibility are revised so that they meet the eligibility criteria. Suggestions and comments submitted by each expert, it will be used as material to perfect the Islamic education material / textbook developed.

After the results of the design of the teaching material product were revised based on suggestions from the validator, the revised results were then tested at SMK Negeri 4 Manado. The implementation of this limited trial aims to determine the level of practicality and effectiveness of the developed multicultural perspective Islamic Education teaching materials.

Analysis of the practicality of Islamic Education teaching material products based on the results of the teacher's response questionnaire and the results of the observations of the teacher's ability to manage learning during the learning process. Based on the results of the teacher response questionnaire, it shows that the teaching material product meets the criteria for potential users. Indications of content feasibility, presentation feasibility, language feasibility, and graphic feasibility show that the mean of 3.67 is in the strongly agree category if converted into percent is at $92.50 \%$. This shows that educators have a positive response to all aspects of the question. Furthermore, the analysis of the practicality of Islamic Education teaching material products is based on the results of the ability of educators in managing learning, obtained from the results of observations of teacher activities during the learning process. In accordance with the results of observations it can be stated that the ability of educators in managing learning using Islamic Education teaching materials with multicultural perspective is in the interval $1.5 \leq \mathrm{KM} \leq 2.0$, which means that the overall average implementation of each activity is carried out entirely. So, the product of Islamic Education teaching materials with a multicultural perspective that has been developed has met practical criteria.

The analysis of the effectiveness of teaching material products was obtained from the results of the analysis of the responses of participants who had received a limited test assessment of 30 students at SMKN 4 Manado, indicating that of 
the 30 respondents surveyed about the responses of students to Islamic Education teaching material products with a multicultural perspective, there were 9 respondents (30.0\%) gave interesting responses, 21 respondents $(70.0 \%)$ gave very interesting responses. Based on these data, most of the 30 respondents who were surveyed stated that it was very interesting to use Islamic Education teaching materials with a multicultural perspective. On average, students are happy with the presentation of the material in the textbook so that students are provoked to have discussions with other students.

Analysis of the effectiveness of teaching material products is based on the analysis of the observation sheet activities of students showing that during the learning process takes place, students are actively involved so that the dominance of educators in learning is relatively reduced. In general, the results of the data analysis on the involvement of students from the first meeting to the last were in the tolerance limit range according to the predetermined effectiveness criteria, which was at a value of 3.4, this value was in the "very high" category. When converted into a percentage of $85 \%$ it is in the high category, thus the involvement of students in the learning process can be categorized as ideal.

Analysis of the effectiveness of teaching material products is also shown from the results of the analysis of learning outcomes in the form of pre-test and post-test. Pre test and post test are given in two forms, the first is the result of the test in the form of an objective test (multiple choice). Based on the results of the pre-test and post-test, it shows that there is an average difference between the pre-test and post-test learning outcomes, which means that there is an effect of the use of multicultural perspective Islamic education teaching materials at SMKN 4 Manado on learning outcomes of Islamic education. The second pre test and post test is a performance test, which is to provide several verses of the Koran to students to read according to good and correct recitation, then students are directed to explain their understanding of the verses of the Koran that have been read. Based on the results of the pre-test and post-test, it shows that there is an average difference between the pre-test and post-test performance tests, which means that there is an influence on the use of Islamic education teaching materials with a multicultural perspective. Thus, based on several analyzes of the effectiveness of teaching material products that have been carried out by referring to the specified effectiveness criteria, it can be said that the multicultural perspective Islamic education teaching material products developed have met the effective criteria for use in the learning process.

The last stage of development is the disseminate stage. Activities in this stage of dissemination in the form of socialization are carried out by conducting FGD (Focus Group Discussion). Through FGD, Islamic Education teaching materials with a multicultural perspective are introduced to teachers who are included in the Islamic Education MGMP (Subject Teacher Conference). This introduction is by looking at the contents of the book that are in accordance with the 2013 curriculum and conveying how quickly students understand the content of teaching materials with a multicultural perspective. Coordinator for FGD said that the teacher was very enthusiastic in accepting the teaching material because it was very helpful in teaching Islamic Education which was fun and easily understood by students.

Based on the description of the research results, it can be stated that the teaching material products developed have met the criteria of being valid, practical, and effective. The validity of teaching material products is a very important part in development research as a condition for the feasibility of a teaching material product to be used in the trial phase. This is in accordance with the view of Nieveen (2010) [16] which states that one of the stages to obtain good learning tools is through the expert / expert validation and revision stages.

The practicality of teaching material products is an indication of the success of educators in carrying out the entire stages of the learning process by using teaching materials or learning tools that have been developed. It is in line with Ibrahim (2000: 3) [19], that educators in the classroom need a number of learning tools / devices that will help and facilitate the learning process.

The effectiveness of Islamic Education teaching material products shows the achievement of learning objectives and research and development activities. The effectiveness of the product shows that educators and students have an understanding according to the expected needs. For prospective users, the products that have been produced have provided convenience, acceptance and provided a positive response to Islamic Education teaching materials with a multicultural perspective and are effective in increasing the cognitive abilities and understanding of students. Teaching material products developed as supplement books for students have enormous benefits in accordance with the opinion (Rena, 2014) [20] that student supplement books are an important component to increase learning motivation and learning outcomes of students and have very large benefits including: providing experience learn directly and concretely to students, provide accurate and up-to-date information, and provide positive motivation if its use is arranged and planned appropriately.

\section{CONCLUSION}

Teaching material developed in the form of supplementary books for students is a multicultural perspective Islamic Education teaching material that has fulfilled valid, practical, and effective criteria so that it can be used. Based on the results of limited trials on the target group, the product development of Islamic Education teaching materials with a multicultural perspective has met the criteria as a good teaching material. From the Islamic Education teaching materials practicality criteria in terms of content worthiness, presentation, language, and graphics based on responses from Islamic Education educators / teachers and observations of the implementation of the use of Islamic Education teaching material 
products indicate an excellent level of practicality thus the Islamic Education teaching material products with multicultural perspective meet the criteria practicality and feasible to use in testing are limited to research objectives. Meanwhile, from the aspect of the effectiveness of using Islamic Education teaching materials, it can be seen that the results of students' responses to Islamic Education teaching material products show that $70 \%$ of students give very interesting responses to products that have been developed. In addition to the results of student responses, the results of observations of student activities strengthen the effectiveness of Islamic Education teaching material products, it can be seen that the level of student involvement in learning is at the level of $85 \%$ very high category, so it can be categorized as an effective teaching material to use. This is also strengthened by the results of the implementation of the pre-test and post-test in the form of objective and performance tests that have been carried out showing that there are differences between the pre-test learning outcomes with the post-test which means that there is an influence of the use of multicultural perspective Islamic education teaching materials on the results of the tests conducted at SMKN 4 Manado. Significantly, Islamic Education teaching materials in multicultural perspective are effective in improving students' cognitive and religious understanding.

\section{REFERENCES}

[1] Syahidin. Menelusuri Metode Pendidikan dalam Al-Qur`an. Bandung: Alfabeta; 2009.

[2] Tilaar HAR. Perubahan sosial dan pendidikan : pengantar pedagogik transformatif untuk Indonesia. Jakarta: PT. Gramedia Widiasarana Indonesia; 2002.

[3] Banks JA, Banks CAM. Multicultural Education: Issues and Perspectives [Internet]. 7th Edition. Unites States of America: John Wiley \& Sons; 2010 [cited 2020 Aug 13]. Available from: http://docshare01.docshare.tips/files/20751/207517255.pdf

[4] Dantes N. Pengembangan Kurikulum Berwawasan Multikultural [Internet]. adoc.tips. 2015 [cited 2020 Aug 13]. Available from: https://adoc.tips/pengembangan-kurikulum-berwawasan-multikultural.html

[5] Nieto S. Language, Culture, and Teaching: Critical Perspectives for a New Century [Internet]. Mahwah: NJ: Lawrence Erlbaum Associates; 2002 [cited 2020 Aug 13]. Available from: http://www.teslej.org/wordpress/issues/volume5/ej20/ej20r9/

[6] Daryanto, Dwicahyono A. Pengembangan perangkat pembelajaran : (silabus, RPP, PHB, bahan ajar). Yogyakarta: Gava Media; 2014.

[7] Mudlofir HA. Aplikasi pengembangan kurikulum tingkat satuan pendidikan dan bahan ajar dalam pendidikan agama Islam. Jakarta: Rajawali Pers; 2011.

[8] Setiawan D. Pengembangan Bahan Ajar. Tangerang Selatan: Universitas Terbuka; 2012.

[9] Jufni M, Ibrahim S. Kreativitas Guru PAI dalam Pengambangan Bahan Ajar di Madrasah Aliyah Jeumala Amal Lueng Putu. 2015;3(4):10.

[10] Departemen Pendidikan Nasional. Panduan Pengembangan Bahan Ajar. Jakarta: Departemen Pendidikan Nasional; 2008.

[11] Harto K. MODEL PENGEMBANGAN PENDIDIKAN AGAMA ISLAM BERBASIS MULTIKULTURAL. AlTahrir: Jurnal Pemikiran Islam. 2014 Nov 1;14(2):407-426-426.

[12] Naim N, Sauqi A. Pendidikan multikultural : konsep dan aplikasi. Yogyakarta: Ar-Ruzz Media; 2008.

[13] Hanum F. Sosiologi pendidikan. Yogyakarta: Kanwa Publisher; 2011.

[14]Zubaedi. Pendidikan Berbasis Masyarakat. Yogyakarta: Pustaka Pelajar; 2005.

[15] Thiagarajan S, Semmel DS, Semmel MI. Instructional Development for Training Teachers of Exceptional Children. University of Minnesota: Leadership training institute/special education; 1974.

[16] Plomp T, Nieveen NM. An introduction to educational design research: proceedings of the seminar conducted at the East China Normal University, Shanghai (PR China), November 23-26, 2007 [Internet]. 2010 [cited 2020 Mar 5]. $\quad$ Available

from: http://www.slo.nl/downloads/2009/Introduction_20to_20education_20design_20research.pdf/download

[17] Arsyad N. Model Pembelajaran Matematika yang Menumbuhkan Kemampuan Metakognisi untuk Menguasai Bahan Ajar. Disertasi tidak diterbitkan Surabaya: PPs Universitas Negeri Surabaya. 2007;

[18] Hobri. Metodologi Penelitian Pe-ngembangan (Aplikasi pada Penelitian Pendidikan Matematika). Jember: Pena Salsabila; 2010.

[19] Ibrahim, Muslimin. Pembelajaran Kooperatif. Surabaya: Universitas Surabaya Press; 2000.

[20] Rena. PENGARUH BUKU PENUNJANG SEBAGAI SUMBER BELAJAR TERHADAP MOTIVASI DAN HASIL BELAJAR SISWA PADA MATA PELAJARAN GEOGRAFI DI MADRASAH ALIYAH ALKHAIRAAT TONDO PALU [Internet]. 2014 [cited 2020 Aug 14]. Available from: https://docplayer.info/50918343-Rena-a-jurnal-mahasiswa-program-studi-pendidikan-geografi-p-ips-fkip-untadpenerbit-e-journal-geo-tadulako-untad.html 